\title{
SOLUSI ALIRAN DAYA UNTUK SISTEM DISTRIBUSI TAK SEIMBANG DENGAN MENGGUNAKAN METODE TRUST-REGION
}

\author{
Rudy Gianto dan Kho Hie Khwee \\ Jurusan Teknik Elektro, Fakultas Teknik, Universitas Tanjungpura \\ e-mail: rudygianto@gmail.com
}

\begin{abstract}
Abstrak - Pada penelitian ini, telah dibahas penggunaan dari metode trust-region untuk menyelesaikan masalah aliran daya pada sistem distribusi tak-seimbang. Metode yang diusulkan tersebut telah berhasil diaplikasikan pada pada tiga buah sistem distribusi tak-seimbang yaitu: sistem 10-bus, 19-bus dan 25-bus. Hasil-hasil penelitian memperlihatkan bahwa nilai-nilai yang diperoleh melalui metode trust-region adalah sangat sesuai dengan nilai-nilai yang didapat melalui metode lain yang sebelumnya telah dipublikasikan
\end{abstract}

Kata Kunci : aliran daya, sistem distribusi, metode trust-region

\begin{abstract}
In this research, the trust-region method has been proposed for solving the power flow problem of an unbalanced distribution system. The proposed method has been successfully applied in solving the power flow problems of three unbalanced distribution networks, i.e. 10-bus, 19-bus and 25-bus systems. The results of investigation obtained by the proposed method were compared to the previously reported results and were found to be in exact agreement
\end{abstract}

Keywords : power flow, distribution system, trust-region method

\section{PENDAhUluan}

Aliran daya (atau aliran beban) merupakan solusi untuk kondisi operasi keadaan normal dari suatu sistem tenaga listrik. Secara umum, perhitungan aliran daya dilakukan untuk perencanaan sistem tenaga, perencanaan operasional dan untuk operasi dan kendali sistem. Data yang diperoleh dari studi aliran daya digunakan untuk studi operasi normal, analisis kontingensi, penjadwalan optimum pembangkitan tenaga listrik dan studi-studi stabilitas.

Sebelum tahun 1929, semua perhitungan aliran daya dilakukan dengan tangan. Pada tahun 1929, network calculators (dari Westinghouse) atau network analyzers (dari General Electric) digunakan untuk melakukan perhitungan aliran daya. Tulisan pertama yang menjelaskan metode digital untuk penyelesaian masalah aliran daya dipublikasikan pada tahun 1954. Namun demikian, metode digital pertama yang sukses dikembangkan adalah oleh Ward dan Hale pada tahun 1956. Metoda iteratif yang digunakan pada awalnya didasarkan pada matriks-Y dari metoda Gauss-Seidel. Metoda ini memerlukan simpanan komputer yang minimum dan iterasi yang sedikit untuk sistem yang kecil. Namun, bila ukuran sistem bertambah besar, jumlah iterasi yang diperlukan meningkat secara dramatis. Pada beberapa kasus, metoda ini sama sekali tidak memberikan solusi.

Kekurangan dari metoda Gauss-Seidel diatas memicu dikembangkannya metoda NewtonRaphson. Metoda ini awalnya dikembangkan oleh Van Ness dan Griffin dan kemudian dikembangkan lagi oleh peneliti-peneliti lain seperti Tinney dan Stot. Metoda ini didasarkan pada algoritma Newton-Raphson untuk penyelesaian persamaan kuadratik simultan dari jaringan daya.

Berlawanan dengan algoritma Gauss-Seidel, metoda Newton-Raphson memerlukan waktu yang lebih panjang per-iterasinya, namun jumlah iterasinya sedikit dan tidak tergantung pada ukuran jaringan. Oleh karenanya, masalah aliran daya yang tidak dapat diselesaikan dengan metoda Gauss-Seidel dapat diselesaikan secara mudah dengan metoda ini. Metode ini semakin atraktif dengan dikembangkannya teknik eliminasi yang sangat efisien oleh Tinney dkk. Hal ini sangat meningkatkan efisiensi dari metode Newton-Raphson terutama dalam hal kecepatan dan penggunaan memori komputer yang digunakan sehingga memungkinkan untuk digunakan pada sistem tenaga listrik yang berukuran besar.

Keunggulan-keunggulan dari metode 
Newton-Raphson diatas telah mengakibatkan metode tersebut digunakan secara luas untuk menyelesaikan masalah aliran daya pada suatu sistem transmisi tenaga listrik. Namun demikian, aplikasi dari metode tersebut pada sistem distribusi tenaga listrik dapat menimbulkan masalah konvergensi sehingga solusi aliran daya menjadi sulit atau tidak bisa diperoleh. Hal ini pada gilirannya dapat membuat perencanaan sistem menjadi tidak dapat dilakukan dan pengoperasian serta pengendalian sistem menjadi terganggu.

Untuk mencegah terjadinya hal-hal seperti ini, maka perlu dilakukan suatu kajian mengenai upaya-upaya untuk mengembangkan metode solusi aliran daya yang andal dan efisien yang dapat mengatasi masalah diatas sehingga perencanaan dan pengoperasian sistem menjadi mudah untuk dilaksanakan.

\section{TINJAUAN PUSTAKA}

Beberapa kajian terhadap metode solusi masalah aliran daya telah dilakukan oleh beberapa peneliti seperti yang dilaporkan pada Ref.[1-5]. Para peneliti ini telah mengusulkan metode atau teknik yang didasarkan pada skema iteratif Newton-Raphson. Metode ini telah digunakan secara luas dalam menyelesaikan masalah aliran daya pada sistem-sistem transmisi tenaga listrik. Namun demikian, metode ini dapat menimbulkan masalah konvergensi bila diterapkan pada sistem distribusi tenaga listrik sehingga solusinya menjadi sulit atau tidak bisa diperoleh.

Peneliti lain yang juga telah melakukan kajian terhadap metode solusi masalah aliran daya adalah seperti yang dilaporkan pada Ref.[610]. Para peneliti ini menggunakan metode atau teknik yang memanfaatkan struktur radial dari sistem distribusi tenaga listrik. Teknik ini dikenal juga sebagai teknik penyapuan maju/mundur (forward/backward sweeping technique) dan dalam mencari solusinya ia tidak menggunakan skema iteratif Newton-Raphson. Kekurangan dari metode ini adalah ia memerlukan teknik penomoran cabang (branch numbering) dan pengurutan bus (bus ordering) yang cukup rumit terutama bila sistemnya berukuran besar.

Pada metode yang diusulkan pada penelitian ini, masalah solusi aliran daya akan diselesaikan dengan metode trust-region. Metode trust- region merupakan metode yang cukup populer dan biasa digunakan untuk menyelesaikan masalah-masalah optimisasi.

Akhir-akhir ini beberapa peneliti telah melakukan kajian terhadap metode trust-region untuk diaplikasikan pada penyelesaian sistemsistem persamaan nonlinier seperti yang dilaporkan pada Ref.[11-14]. Hasil kajian menunjukkan bahwa metode ini sangat potensial untuk digunakan sebagai salah satu cara penyelesaian sistem-sistem persamaan nonlinier. Hasil kajian peneliti tersebut juga memperlihatkan bahwa metode trust-region dapat mengatasi kasus-kasus matriks Jacobian yang singulir.

Oleh karena persamaan yang timbul dalam formulasi masalah aliran daya adalah persamaan-persamaan nonlinear, maka sudah barang tentu metode tersebut juga memiliki potensi untuk diaplikasikan pada penyelesaian masalah aliran daya pada sistem distribusi tenaga listrik. Hal inilah yang akan diselidiki dan dikembangkan pada penelitian ini.

\section{METODOLOGI ATAU TEORI}

\subsection{Formulasi Masalah Aliran Daya}

Masalah aliran daya dapat didefinisikan sebagai perhitungan tegangan-tegangan bus dari suatu sistem tenaga listrik pada kondisi beban dan pembangkitan tertentu. Setelah tegangantegangan bus ini dihitung, selanjutnya kita dapat menghitung besarnya suplai daya, aliran daya dan rugi-rugi daya pada saluran transmisi.

Dapat ditunjukkan bahwa tegangantegangan bus sistem dapat dihitung dengan cara menyelesaikan persamaan-persamaan berikut:

$$
\left\{\begin{array}{l}
-P_{G i}+P_{L i}+\sum_{j=1}^{n}\left|V_{i}\right|\left|Y_{i j}\right|\left|V_{j}\right| \cos \left(\delta_{i}-\delta_{j}-\theta_{i j}\right)=0 \\
-Q_{G i}+Q_{L i}+\sum_{j=1}^{n}\left|V_{i}\right|\left|Y_{i j}\right|\left|V_{j}\right| \sin \left(\delta_{i}-\delta_{j}-\theta_{i j}\right)=0
\end{array}\right.
$$

dimana:

$P_{G i}, Q_{G i} \quad$ : daya aktif, reaktif yang disuplai pada bus ke- $i$

$P_{L i}, Q_{L i} \quad$ : daya aktif, reaktif beban pada bus ke- $i$

$V_{i}=\left|V_{i}\right| e^{j \delta_{i}}:$ tegangan pada bus ke- $i$ 


$$
\begin{aligned}
Y_{i j}=\left|Y_{i j}\right| e^{j \theta_{i j}}: & \text { elemen ke-ij dari matriks } \\
n & \text { admitansi bus } \\
& : \text { jumlah bus dalam sistem } \\
& \text { tenaga listrik }
\end{aligned}
$$

Persamaan (1) merupakan seset persamaan nonlinier dan menyatakan $2 n$ persamaan aliran daya untuk $n$ bus sistem tenaga. Oleh karena studi aliran daya biasanya dilakukan pada kondisi beban tertentu, maka $P_{L i}$ dan $Q_{L i}$ akan diketahui nilainya.

Lebih lanjut, pada bus penyuplai daya (bus 1), besarnya tegangan biasanya telah ditentukan atau dispesifikasi. Sehingga pada bus ini besaran-besaran yang akan dicari adalah suplai daya aktif dan reaktif atau $P_{G I}$ dan $Q_{G I}$. Sedangkan pada bus-bus lainnya (bus $2,3, \ldots, n$ ), $P_{G l}$ dan $Q_{G l}$ adalah nol karena bus-bus ini tidak memiliki suplai daya. Dengan demikian, pada bus-bus ini besaran-besaran yang akan dicari adalah besar tegangan dan sudut fasanya atau $V_{i}$ dan $\delta_{i}$.

Setelah persamaan (1) diatas berhasil diselesaikan, maka aliran daya dan rugi-rugi daya pada saluran-saluran dapat dihitung.

\subsection{Solusi Aliran Daya (Metode Newton- Raphson)}

Persamaan (1) merupakan seset persamaan nonlinier yang dapat diselesaikan dengan metode Newton-Raphson. Dalam mencari solusi, metode Newton-Raphson menggunakan teknik iteratif. Dengan teknik iteratif ini, pencarian solusi dimulai dengan estimasi awal untuk variabel yang ingin dicari. Estimasi tersebut kemudian diperbaiki secara berturutan sampai solusi yang diinginkan diperoleh. Apabila solusinya telah didapat, maka dikatakan bahwa solusinya telah konvergen.

Berikut adalah penjelasan mengenai penggunaan metode Newton-Raphson pada sistem persamaan nonlinier umum. Misalkan seset persamaan nonlinier dengan jumlah persamaan $n$ diberikan oleh:

$$
\boldsymbol{F}(\boldsymbol{x})=\left[\begin{array}{c}
f_{1}\left(x_{1}, x_{2}, \ldots, x_{n}\right) \\
f_{2}\left(x_{1}, x_{2}, \ldots, x_{n}\right) \\
\vdots \\
f_{n}\left(x_{1}, x_{2}, \ldots, x_{n}\right)
\end{array}\right]=\boldsymbol{0}
$$

dimana $\quad \boldsymbol{x}=\left[\begin{array}{llll}x_{1} & x_{2} & \cdots & x_{n}\end{array}\right]^{T} \quad$ adalah variabel yang akan dicari.

Langkah iteratif dari metode NewtonRaphson dalam mencari solusi adalah dengan menyelesaikan persamaan berikut secara berurutan:

$$
\boldsymbol{x}^{(k+1)}=\boldsymbol{x}^{(k)}+\boldsymbol{d}^{(k)}
$$

dimana:

$$
\boldsymbol{d}^{(k)}=-\left[\boldsymbol{J}\left(\boldsymbol{x}^{(k)}\right)\right]^{-1} \boldsymbol{F}\left(\boldsymbol{x}^{(k)}\right)
$$

Pada persamaan (4), $\boldsymbol{J}(\boldsymbol{x})$ merupakan Jacobian dari $\boldsymbol{F}(\boldsymbol{x})$ dan dihitung melalui:

$$
\boldsymbol{J}(\boldsymbol{x})=\left[\begin{array}{cccc}
\frac{\partial f_{1}}{\partial x_{1}} & \frac{\partial f_{1}}{\partial x_{2}} & \cdots & \frac{\partial f_{1}}{\partial x_{n}} \\
\frac{\partial f_{2}}{\partial x_{1}} & \frac{\partial f_{2}}{\partial x_{2}} & \cdots & \frac{\partial f_{2}}{\partial x_{n}} \\
\vdots & \vdots & \ddots & \vdots \\
\frac{\partial f_{n}}{\partial x_{1}} & \frac{\partial f_{n}}{\partial x_{2}} & \cdots & \frac{\partial f_{n}}{\partial x_{n}}
\end{array}\right]
$$

Dengan demikian, langkah-langkah dari metode Newton-Raphson dalam mencari solusi adalah seperti berikut:

1. Set $k=0$, tentukan estimasi awal untuk solusi $\boldsymbol{x}^{(k)}$ dan toleransi $\varepsilon$.

2. Cek apakah: maks $\left|\boldsymbol{F}\left(\boldsymbol{x}^{(k)}\right)\right|<\varepsilon$. Jika ya, stop dan solusinya adalah $\boldsymbol{x}^{(k)}$. Jika tidak, lanjutkan ke Langkah 3.

3. Hitung Jacobian $\boldsymbol{J}\left(\boldsymbol{x}^{(k)}\right)$ dan $\boldsymbol{d}^{(k)}$.

4. Hitung $\boldsymbol{x}^{(k+1)}$ melalui (3).

5. Set $k=k+1$, dan kembali ke Langkah 2 .

\subsection{Solusi Aliran Daya (Metode Trust-Region)}

Seperti yang telah diuraikan sebelumnya, metode Newton-Raphson dapat gagal dalam mendapatkan solusi. Hal ini dapat terjadi pada kasus matriks Jacobian yang singulir yang mengakibatkan faktor koreksi Newton $\boldsymbol{d}^{(k)}$ menjadi tidak bisa dihitung karena persamaan (4) tidak dapat diselesaikan. Hal ini dapat diatasi dengan menggunakan metode trust-region yang dapat dijelaskan secara ringkas sebagai berikut.

Seperti yang juga telah diuraikan, pada metode Newton-Raphson, faktor koreksi $\boldsymbol{d}^{(k)}$ 
dihitung dengan menyelesaikan persamaan berikut:

$$
\boldsymbol{F}\left(\boldsymbol{x}^{(k)}\right)+\boldsymbol{J}\left(\boldsymbol{x}^{(k)}\right) \boldsymbol{d}^{(k)}=0
$$

Dapat dibuktikan bahwa solusi terhadap sistem persamaan linier (6) adalah merupakan solusi dari masalah optimisasi berikut:

$$
\min _{\boldsymbol{d}^{(k)}}\left\|q\left(\boldsymbol{d}^{(k)}\right)\right\|^{2}
$$

Pada (7), $q\left(\boldsymbol{d}^{(k)}\right)$ didefinisikan sebagai berikut:

$$
q\left(\boldsymbol{d}^{(k)}\right)=\frac{1}{2} h\left(\boldsymbol{x}^{(k)}\right)+\boldsymbol{d}^{(k) T} \boldsymbol{g}\left(\boldsymbol{x}^{(k)}\right)+\frac{1}{2} \boldsymbol{d}^{(k) T} \boldsymbol{H}\left(\boldsymbol{x}^{(k)}\right) \boldsymbol{d}^{(k)}
$$

dimana:

$$
\begin{aligned}
h\left(\boldsymbol{x}^{(k)}\right) & =\boldsymbol{F}\left(\boldsymbol{x}^{(k)}\right)^{T} \boldsymbol{F}\left(\boldsymbol{x}^{(k)}\right) \\
\boldsymbol{g}\left(\boldsymbol{x}^{(k)}\right) & =\boldsymbol{J}\left(\boldsymbol{x}^{(k)}\right)^{T} \boldsymbol{F}\left(\boldsymbol{x}^{(k)}\right) \\
\boldsymbol{H}\left(\boldsymbol{x}^{(k)}\right) & =\boldsymbol{J}\left(\boldsymbol{x}^{(k)}\right)^{T} \boldsymbol{J}\left(\boldsymbol{x}^{(k)}\right)
\end{aligned}
$$

Oleh karenanya, daripada menyelesaikan persamaan (6) yang mungkin bisa gagal mendapatkan solusi, faktor koreksi $\boldsymbol{d}^{(k)}$ dapat dihitung dengan menyelesaikan (7). Untuk menghindari ketidak-tentuan atau agar proses pencarian solusi menjadi teratur, nilai $\left\|\boldsymbol{d}^{(k)}\right\|$ harus dibatasi atau diberi konstrain pada suatu nilai tertentu yang biasa disebut sebagai radius dari trust-region. Sehingga, faktor koreksi $\boldsymbol{d}^{(k)}$ dapat dihitung dengan menyelesaikan masalah optimisasi seperti berikut:

$$
\begin{aligned}
& \min _{\boldsymbol{d}^{(k)}}\left\|q\left(\boldsymbol{d}^{(k)}\right)\right\|^{2} \\
& \text { dengan konstrain: }\left\|\boldsymbol{d}^{(k)}\right\| \leq \Delta^{(k)}
\end{aligned}
$$

dimana $\Delta^{(\mathrm{k})}>0$ adalah radius dari trust-region.

Satu hal penting dalam metode trust-region adalah pemilihan dari radius trust-region $\Delta^{(\mathrm{k})}$ pada setiap iterasi. Pemilihan ini biasanya didasarkan pada kecocokan antara fungsi $h\left(\boldsymbol{x}^{(\mathrm{k})}\right)$ dan $q\left(\boldsymbol{x}^{(\mathrm{k})}\right)$. Untuk keperluan ini, kita definisikan rasio:

$$
r^{(k)}=\frac{h\left(\boldsymbol{x}^{(k)}\right)-h\left(\boldsymbol{x}^{(k)}+\boldsymbol{d}^{(k)}\right)}{q\left(\boldsymbol{x}^{(k)}=0\right)-q\left(\boldsymbol{x}^{(k)}\right)}
$$

Numerator pada (11) biasa disebut sebagai reduksi aktual (actual reduction), sedangkan denominatornya biasa disebut sebagai reduksi perkiraan (predicted reduction).

Rasio $r^{(\mathrm{k})}$ memiliki peranan penting dalam penentuan nilai iterasi yang baru $\boldsymbol{x}^{(\mathrm{k}+1)}$ dan besarnya radius trust-region $\Delta^{(\mathrm{k}+1)}$. Jika $r^{(\mathrm{k})}$ mendekati 1 (misalnya $r^{(\mathrm{k})}>0,75$ ), maka terdapat kecocokan antara $h\left(\boldsymbol{x}^{(\mathrm{k})}\right)$ dan $q\left(\boldsymbol{x}^{(\mathrm{k})}\right)$ dan kita dapat memperbesar radius trust-region pada iterasi berikutnya. Jika $r^{(\mathrm{k})}$ mendekati 0 atau negatif (misalnya $r^{(\mathrm{k})}<0,01$ ), maka kita harus memperkecil radius trust-region pada iterasi berikutnya. Dilain pihak, jika $r^{(\mathrm{k})}$ positif tetapi lebih kecil dari 1 (misalnya $0,01<r^{(\mathrm{k})}<0,75$ ), maka radius trust-region pada iterasi berikutnya tidak perlu diubah. Dengan demikian, langkahlangkah dari metode trust-region dalam mencari solusi adalah seperti berikut:

1. Set: $k=0$, estimasi awal untuk solusi $\boldsymbol{x}^{(k)}$, radius trust-region $\Delta^{(\mathrm{k})}>0$, dan toleransi $\varepsilon$.

2. Cek apakah: $h\left(\boldsymbol{x}^{(k)}\right) \mid<\varepsilon$. Jika ya, stop dan solusinya adalah $\boldsymbol{x}^{(k)}$. Jika tidak, lanjutkan ke Langkah 3.

3. Hitung faktor koreksi $\boldsymbol{d}^{(k)}$ melalui (10).

4. Hitung rasio $r^{(k)}$ melalui (11), dan set nilai solusi yang baru melalui:

$$
\boldsymbol{x}^{(k+1)}\left\{\begin{array}{l}
\boldsymbol{x}^{(k)}+\boldsymbol{d}^{(k)} ; \text { Jika } r^{(k)} \geq 0 \\
\boldsymbol{x}^{(k)} ; \text { Jika } r^{(k)}<0
\end{array}\right.
$$

5. Set radius trust-region yang baru melalui:

$$
\Delta^{(k+1)}\left\{\begin{array}{l}
2 \Delta^{(k)} ; \text { Jika } r^{(k)}>0,75 \\
0,25 \Delta^{(k)} ; \text { Jika } r^{(k)}<0,01 \\
\Delta^{(k)} ; \text { Jika } 0,01 \leq r^{(k)} \leq 0,75
\end{array}\right.
$$

6. Set $k=k+1$, dan kembali ke Langkah 2 .

\section{HASIL DAN PEMBAHASAN}

\subsection{Umum}

Performansi dari metode yang diusulkan pada Subbab 3.3 akan diselidiki dengan cara mengaplikasikannya pada tiga buah sistem distribusi tak-seimbang yaitu: sistem 10-bus, 19- 
bus dan 25-bus. Perlu juga ditambahkan disini bahwa semua perhitungan pada penelitian ini dilakukan pada komputer PC, dan algoritma perhitungan dari metode yang diusulkan tersebut diimplementasikan sebagai kode MATLAB (mfile).

\subsection{Sistem Test}

Tiga buah sistem distribusi tak-seimbang yang digunakan sebagai sistem test untuk menyelidiki penampilan dari metode yang diusulkan adalah sebagai berikut:

\subsubsection{Sistem 10-bus}

Sistem ini adalah sistem dengan tegangan 8,66 $\mathrm{kV}$ dimana diagram segarisnya diperlihatkan pada Gambar 1 [9].

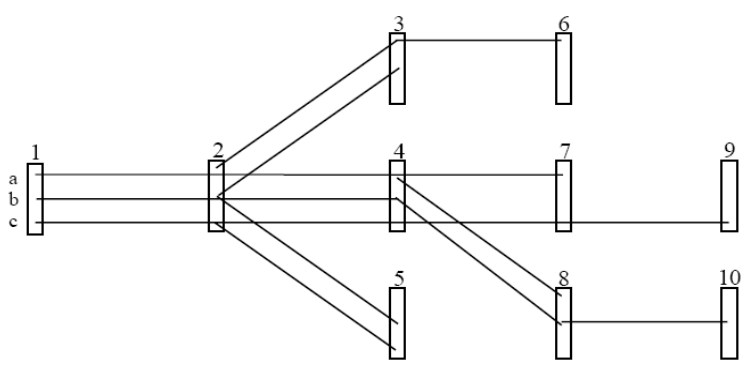

Gambar 1. Diagram segaris sistem 10-bus

\subsubsection{Sistem 19-bus}

Sistem ini adalah sistem dengan tegangan $11 \mathrm{kV}$ dimana diagram segarisnya diperlihatkan pada Gambar $2[15,16]$.

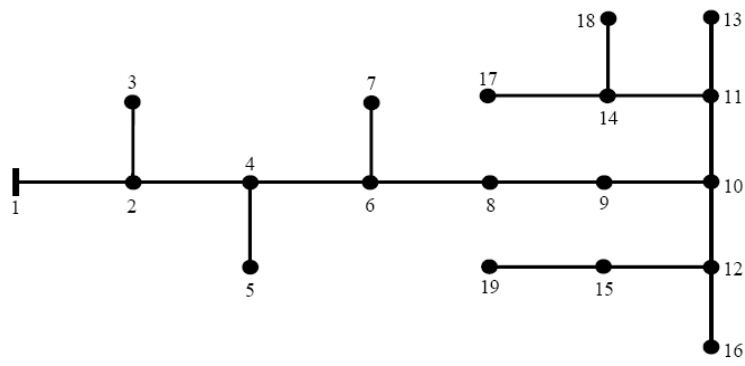

Gambar 2. Diagram segaris sistem 19-bus

\subsubsection{Sistem 25 -bus}

Sistem ini adalah sistem dengan tegangan $4,16 \mathrm{kV}$ dimana diagram segarisnya diperlihatkan pada Gambar $3[7,9,15]$.

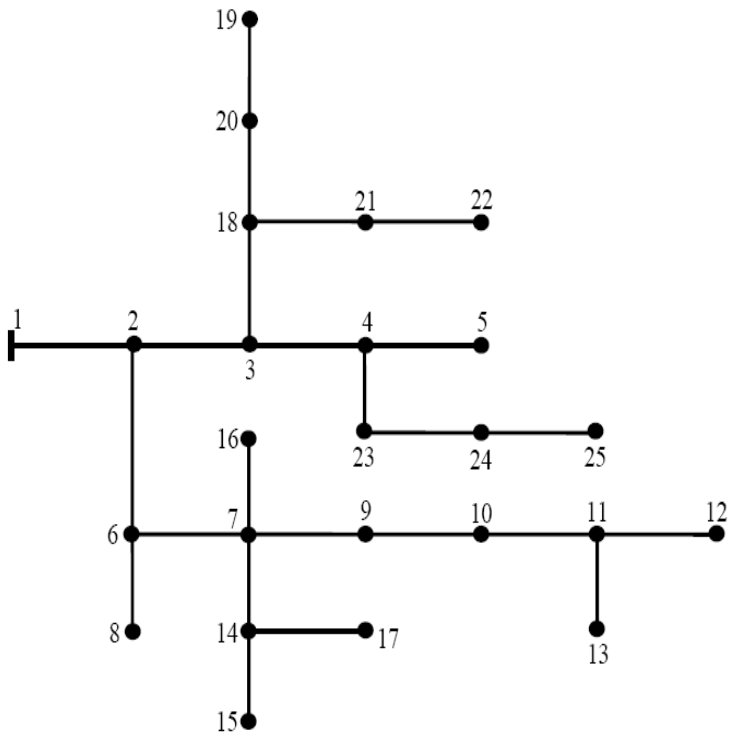

Gambar 3. Diagram segaris sistem 25-bus

\subsection{Hasil dan Pembahasan}

Hasil-hasil perhitungan yang diperoleh melalui aplikasi dari metode yang diusulkan pada sistem 10-bus, 19-bus dan 25-bus berturutturut diperlihatkan pada Tabel 1, 2 dan 3.

Tabel 1. Profil tegangan untuk sistem 10-bus

\begin{tabular}{|c|c|c|c|}
\hline \multirow{2}{*}{ Bus } & \multicolumn{3}{|c|}{ Tegangan (pu) } \\
\cline { 2 - 4 } & Fasa a & Fasa b & Fasa c \\
\hline 1 & $1,00000 \angle 0,00^{0}$ & $1,00000 \angle-120,00^{0}$ & $1,00000 \angle 120,00^{0}$ \\
\hline 2 & $0,95564 \angle-1,21^{0}$ & $0,99303 \angle-120,57^{0}$ & $0,98638 \angle 119,98^{0}$ \\
\hline 3 & $0,94458 \angle 1,32^{0}$ & $0,99295 \angle-120,64^{0}$ & $0,98638 \angle 119,98^{0}$ \\
\hline 4 & $0,93059 \angle-1,96^{0}$ & $0,99165 \angle-120,75^{0}$ & $0,97844 \angle 120,08^{0}$ \\
\hline 5 & $0,95564 \angle-1,21^{0}$ & $0,99063 \angle-120,61^{0}$ & $0,98423 \angle 119,89^{0}$ \\
\hline 6 & $0,91901 \angle-1,19^{0}$ & $0,99295 \angle-120,64^{0}$ & $0,98638 \angle 119,98^{0}$ \\
\hline 7 & $0,92359 \angle-2,02^{0}$ & $0,99165 \angle-120,75^{0}$ & $0,97486 \angle 120,10^{\circ}$ \\
\hline 8 & $0,92268 \angle-1,10^{0}$ & $0,98995 \angle-120,82^{0}$ & $0,97844 \angle 120,08^{0}$ \\
\hline 9 & $0,92359 \angle-2,02^{0}$ & $0,99165 \angle-120,75^{0}$ & $0,96710 \angle 119,94^{0}$ \\
\hline 10 & $0,92268 \angle-1,10^{0}$ & $0,98154 \angle-120,90^{0}$ & $0,97844 \angle 120,08^{0}$ \\
\hline
\end{tabular}

Hasil-hasil pada Tabel 1, 2 dan 3 tersebut memperlihatkan bahwa:

- Nilai-nilai tegangan untuk sistem distribusi 10-bus yang diperoleh melalui metode yang diusulkan bila dibandingkan dengan nilai- 
nilai tegangan seperti yang dilaporkan pada Ref.[9], hasilnya adalah sangat sesuai.

- Nilai-nilai tegangan untuk sistem distribusi 19-bus yang diperoleh melalui metode yang diusulkan bila dibandingkan dengan nilainilai tegangan seperti yang dilaporkan pada Ref.[15, 16], hasilnya adalah sangat sesuai.

- Nilai-nilai tegangan untuk sistem distribusi 25-bus yang diperoleh melalui metode yang diusulkan bila dibandingkan dengan nilainilai tegangan seperti yang dilaporkan pada Ref.[15], hasilnya adalah juga sangat sesuai.

Tabel 2. Profil tegangan untuk sistem 19-bus

\begin{tabular}{|c|c|c|c|}
\hline \multirow{2}{*}{ Bus } & \multicolumn{3}{|c|}{ Tegangan (pu) } \\
\hline & Fasa a & Fasa b & Fasa c \\
\hline 1 & $1,00000 \angle 0,00^{0}$ & $1,00000 \angle-120,00^{0}$ & $1,00000 \angle 120,00^{0}$ \\
\hline 2 & $0,98746 \angle 0,01^{0}$ & $0,98910 \angle-119,98^{0}$ & $0,98798 \angle 120,05^{0}$ \\
\hline 3 & $0,98542 \angle 0,00^{\circ}$ & $0,98869 \angle-119,98^{0}$ & $0,98633 \angle 120,08^{0}$ \\
\hline 4 & $0,98235 \angle 0,03^{0}$ & $0,98390 \angle-119,97^{0}$ & $0,98301 \angle 120,07^{0}$ \\
\hline 5 & $0,98201 \angle 0,03^{0}$ & $0,98366 \angle-119,97^{0}$ & $0,98283 \angle 120,07^{0}$ \\
\hline 6 & $0,97928 \angle 0,04^{0}$ & $0,98078 \angle-119,96^{0}$ & $0,98005 \angle 120,07^{0}$ \\
\hline 7 & $0,97861 \angle 0,04^{0}$ & $0,98029 \angle-119,96^{0}$ & $0,97956 \angle 120,08^{0}$ \\
\hline 8 & $0,97281 \angle 0,07^{0}$ & $0,97381 \angle-119,94^{0}$ & $0,97347 \angle 120,08^{0}$ \\
\hline 9 & $0,96592 \angle 0,09^{0}$ & $0,96598 \angle-119,91^{0}$ & $0,96575 \angle 120,09^{0}$ \\
\hline 10 & $0,95625 \angle 0,08^{0}$ & $0,95549 \angle-119,87^{0}$ & $0,95500 \angle 120,10^{0}$ \\
\hline 11 & $0,95499 \angle 0,10^{0}$ & $0,95429 \angle-119,86^{0}$ & $0,95330 \angle 120,11^{0}$ \\
\hline 12 & $0,95478 \angle 0,11^{0}$ & $0,95377 \angle-119,87^{0}$ & $0,95358 \angle 120,10^{0}$ \\
\hline 13 & $0,95440 \angle 0,10^{0}$ & $0,95344 \angle-119,85^{0}$ & $0,95210 \angle 120,11^{0}$ \\
\hline 14 & $0,95449 \angle 0,10^{0}$ & $0,95388 \angle-119,86^{0}$ & $0,95282 \angle 120,11^{0}$ \\
\hline 15 & $0,95274 \angle 0,12^{0}$ & $0,95122 \angle-119,85^{0}$ & $0,95126 \angle 120,10^{0}$ \\
\hline 16 & $0,95339 \angle 0,13^{0}$ & $0,95147 \angle-119,86^{0}$ & $0,95217 \angle 120,10^{0}$ \\
\hline 17 & $0,95365 \angle 0,10^{\circ}$ & $0,95377 \angle-119,86^{0}$ & $0,95232 \angle 120,12^{0}$ \\
\hline 18 & $0,95380 \angle 0,10^{0}$ & $0,95319 \angle-119,86^{0}$ & $0,95209 \angle 120,11^{0}$ \\
\hline 19 & $0,95159 \angle 0,14^{0}$ & $0,94976 \angle-119,86^{0}$ & $0,95047 \angle 120,10^{0}$ \\
\hline
\end{tabular}

Tabel 3. Profil tegangan untuk sistem 25-bus

\begin{tabular}{|c|c|c|c|}
\hline \multirow{2}{*}{ Bus } & \multicolumn{3}{|c|}{ Tegangan (pu) } \\
\hline & Fasa a & Fasa b & Fasa c \\
\hline 1 & $1,00000 \angle 0,00^{0}$ & $1,00000 \angle-120,00^{0}$ & $1,00000 \angle 120,00^{0}$ \\
\hline 2 & $0,97020 \angle-0,57^{0}$ & $0,97110 \angle-120,41^{0}$ & $0,97545 \angle 119,31^{0}$ \\
\hline 3 & $0,96323 \angle-0,70^{0}$ & $0,96444 \angle-120,52^{0}$ & $0,96984 \angle 119,15^{0}$ \\
\hline 4 & $0,95978 \angle-0,77^{0}$ & $0,96219 \angle-120,57^{0}$ & $0,96739 \angle 119,08^{0}$ \\
\hline 5 & $0,95872 \angle-0,76^{0}$ & $0,96025 \angle-120,57^{0}$ & $0,96644 \angle 119,08^{0}$ \\
\hline 6 & $0,95948 \angle-0,56^{0}$ & $0,95587 \angle-120,36^{0}$ & $0,96148 \angle 119,29^{0}$ \\
\hline 7 & $0,94191 \angle-0,55^{0}$ & $0,94283 \angle-120,30^{0}$ & $0,94923 \angle 119,27^{0}$ \\
\hline 8 & $0,95286 \angle-0,56^{0}$ & $0,95378 \angle-120,35^{0}$ & $0,95957 \angle 119,29^{0}$ \\
\hline 9 & $0,93588 \angle-0,55^{0}$ & $0,93668 \angle-120,28^{0}$ & $0,94379 \angle 119,25^{0}$ \\
\hline 10 & $0,93149 \angle-0,55^{0}$ & $0,93186 \angle-120,26^{0}$ & $0,93953 \angle 119,25^{0}$ \\
\hline 11 & $0,92941 \angle-0,55^{0}$ & $0,92963 \angle-120,26^{0}$ & $0,93763 \angle 119,25^{0}$ \\
\hline 12 & $0,92841 \angle-0,55^{0}$ & $0,92839 \angle-120,25^{0}$ & $0,93659 \angle 119,26^{0}$ \\
\hline 13 & $0,92871 \angle-0,55^{0}$ & $0,92872 \angle-120,26^{0}$ & $0,93682 \angle 119,25^{0}$ \\
\hline 14 & $0,93594 \angle-0,55^{0}$ & $0,93699 \angle-120,27^{0}$ & $0,94338 \angle 119,26^{0}$ \\
\hline 15 & $0,93377 \angle-0,55^{0}$ & $0,93487 \angle-120,27^{0}$ & $0,94144 \angle 119,25^{0}$ \\
\hline 16 & $0,94083 \angle-0,55^{0}$ & $0,94177 \angle-120,30^{0}$ & $0,94826 \angle 119,27^{0}$ \\
\hline 17 & $0,93473 \angle-0,55^{0}$ & $0,93595 \angle-120,27^{0}$ & $0,94203 \angle 119,26^{0}$ \\
\hline 18 & $0,95732 \angle-0,70^{0}$ & $0,95864 \angle-120,50^{0}$ & $0,96432 \angle 119,15^{0}$ \\
\hline 19 & $0,95241 \angle-0,69^{0}$ & $0,95443 \angle-120,49^{0}$ & $0,95998 \angle 119,16^{0}$ \\
\hline 20 & $0,95482 \angle-0,70^{0}$ & $0,95634 \angle-120,49^{0}$ & $0,96201 \angle 119,15^{0}$ \\
\hline 21 & $0,95379 \angle-0,69^{0}$ & $0,95487 \angle-120,49^{0}$ & $0,96053 \angle 119,16^{0}$ \\
\hline 22 & $0,95184 \angle-0,69^{0}$ & $0,95246 \angle-120,48^{0}$ & $0,95852 \angle 119,17^{0}$ \\
\hline 23 & $0,95646 \angle-0,76^{0}$ & $0,95838 \angle-120,57^{0}$ & $0,96479 \angle 119,08^{0}$ \\
\hline 24 & $0,95443 \angle-0,76^{0}$ & $0,95651 \angle-120,57^{0}$ & $0,96311 \angle 119,07^{0}$ \\
\hline 25 & $0,95202 \angle-0,76^{0}$ & $0,95469 \angle-120,57^{0}$ & $0,96117 \angle 119,08^{0}$ \\
\hline
\end{tabular}

\section{KESIMPULAN}

Penelitian ini membahas metode trustregion untuk penyelesaian masalah aliran daya pada sistem distribusi tak-seimbang Metode trust-region merupakan metode yang sangat potensial untuk digunakan sebagai cara penyelesaian sistem persamaan nonlinier. 
Metode ini juga dapat digunakan pada kasus apabila Jacobian dari sistem persamaan adalah singulir.

Pada penelitian ini, metode trust-region telah berhasil diaplikasikan pada pada tiga buah sistem distribusi tak-seimbang yaitu: sistem 10bus, 19-bus dan 25-bus. Hasil-hasil penelitian memperlihatkan bahwa nilai-nilai yang diperoleh melalui metode yang diusulkan tersebut adalah sangat sesuai dengan nilai-nilai yang didapat melalui metode lain yang sebelumnya telah dipublikasikan.

\section{DAFTAR PUSTAKA}

[1] Tinney, W.F., and Hart, C.E.: 'Power Flow Solution by Newton's Method', IEEE Trans. Power App. System, Nov. 1967, Vol. PAS-86, pp. 1449-1459.

[2] Zimmerman, R.D., and Chiang, H.D.: 'Fast Decoupled Power Flow for Unbalanced Radial Distribution Systems', IEEE Trans. Power System, Nov. 1995, Vol. 4, No.10, pp. 2045-2052.

[3] Garcia, P.A.N. et al.: 'Three-Phase Power Flow Calculations Using the Currents Injection Methods', IEEE Trans. Power Systems, May 2000, Vol. 15, No. 2, pp. 508-514.

[4] Teng, J.H., and Chang, C.Y.: 'A Novel and Fast Three-Phase Load Flow for Unbalanced Radial Distribution Systems', IEEE Trans. Power Systems, Nov. 2002, Vol. 17, No. 4, pp. 1238-1244.

[5] Marinho, J.M.T., and Taranto, G.N.: 'A Hybrid Three-Phase Single-Phase Power Flow Formulation', IEEE Trans. Power Systems, August 2008, Vol. 23, No. 3, pp. 1063-1070.

[6] Das, D., et al.: 'Novel Method for Solving Radial Distribution Network', IEE Proc. Gen. Transm. Distrib., Juli 1994, Vol. 141, No. 4.

[7] Goswami, S.K., and Basu S.K.: 'Direct Solution of Distribution Systems', IEE Proc. C, Jan. 1991, Vol. 138, No. 1.

[8] Ghosh, S., and Das D.: 'Method for Load Flow Solution of Radial Distribution Networks', IEE Proc. Gen. Transm. Distrib., Nov. 1999, Vol. 146, No. 6, pp. 641-648.

[9] Ramos, E.R., et al.: 'Quasi-Coupled Three-Phase Radial Load Flow', IEEE
Trans. Power Systems, May 2004, Vol. 19, No. 2, pp. 776-781.

[10] Chang, G.W., et al.: 'An Improved Backward/Forward Sweep Load Flow Algorithm for Radial Distribution Systems', IEEE Trans. Power Systems, May 2007, Vol. 22, No. 2, pp. 882-884.

[11] Zhang, J., and Wang Y.: 'A New Trust Region Method for Nonlinear Equations', Mathematical Methods of Operation Research, Nov. 2003, Vol. 58, Issue 2, pp. 283-298.

[12] Grosan, C., and Abraham A.: 'A New Approach for Solving Nonlinear Equations Systems', IEEE Systems Man and Cybernetics-Part A: Systems and Humans, May 2008, Vol. 38, No. 3, pp. 698-714.

[13] Fan, J., and Pan, J.: 'An Improved Trust Region Algorithm for Nonlinear Equations', Computational Optimization and Aplications, Jan. 2011, Vol. 48, Issue 1, pp. 59-70.

[14] Yuan, Y.: 'Recent Advances in Numerical Methods for Nonlinear Equations', Numerical Algebra Control and Optimization, March 2011, Vol. 1, No. 1, pp. 15-34.

[15] Ganesh, V., Sivanagaraju, S., and Ramana, T.: 'Feeder Reconfiguration for Loss Reduction in Unbalanced Distribution System Using Genetic Algorithm', International Journal of Computer, Electrical, Automation, Control and Information Engineering, 2009, Vol.3, No.4, pp.1050-1058.

[16] Puthireddy, U.R., Sivanagaraju, S., and Prabandhamkam, S.: 'Power Flow Analysis of Three Phase Unbalanced Distribution System', International Journal of Advances in Engineering and Technology, March 2012, Vol.3, No.1, pp.514-524.

\section{Biodata Penulis}

Rudy Gianto, mendapatkan gelar S1, S2 dan S3 berturut-turut dari Universitas Tanjungpura tahun 1991, Institut Teknologi Bandung tahun 1995 dan University of Western Australia tahun 2008. Saat ini penulis terdaftar sebagai dosen Teknik Elektro Universitas Tanjungpura Pontianak. 
Kho Hie Khwee, mendapatkan gelar S1 dan S2 berturut-turut dari Universitas Tanjungpura tahun 1991 dan Institut Teknologi Bandung tahun 1995. Saat ini penulis terdaftar sebagai dosen Teknik Elektro Universitas Tanjungpura Pontianak. 